JOLANTA M. MARSZALSKA*

Wydział Nauk Historycznych

Uniwersytet Kardynała Stefana Wyszyńskiego, Warszawa

ORCID: 0000-0002-5112-5984

\title{
A POLEMICAL HANDWRITTEN MANUSCRIPT IN THE MILIEU OF PLOCK CATHEDRAL AT THE TIME OF THE HUSSITE DISPUTES ${ }^{1}$
}

Hussitism was a religious movement with a strong social and political colouring. Theological issues were generally not known to ordinary people and even to lower clergy, who were not familiar with the complex theological inquiries. For them, the Hussite movement remained a reformist with a clear social and national overtones, through the proclamation of slogans, such as the independence of secular power from clerical power, exemption from annates and tithes, and the resolution of the national conflict in Bohemia. ${ }^{2}$ With regard to the Church, Hussitism demanded a radical reform. From a wide range of issues that were a practical consequence of a specific ecclesiology, the Hussites proposed and formulated in 1420 their doctrinal principles for the reform of the Church, known in historiography as the so-called "Four articles of Prague", which implied: the right to freely proclaim the Word of God; the restoration of Holy Communion under two forms for lay people, reserved since the Lateran

\footnotetext{
* Prof. zw. dr hab. Jolanta M. Marszalska - profesor zwyczajny w Instytucie Historii Wydziału Nauk Historycznych Uniwersytetu Kardynała Stefana Wyszyńskiego w Warszawie. Prowadzi badania nad staropolską kulturą piśmiennictwa, monastycyzmem, księgozbiorami klasztornymi: benedyktynów, cystersów, bernardynów i karmelitów bosych, historycznymi księgozbiorami diecezji tarnowskiej i płockiej oraz księgozbiorami i dziejami rodów magnackich. E-mail:jmmarszalska@wp.pl.

1 This article was based on an analysis of the source material that Adam Vetulani published, see Średniowieczne rękopisy płockiej biblioteki katedralnej, „Roczniki Biblioteczne”, no. 7, vol. 3-4/7 1963, pp. 5-440. The knowledge about this invaluable medieval book collection for the Polish science and culture is currently derived exclusively from the study of A. Vetulani, who before the outbreak of World War II conducted a scientific query in the library of the Seminary in Płock, making notes which were later used to collect and elaborate material in the form of the aforementioned study on medieval manuscript codes in Płock. The work of A. Vetulani is of great importance for getting to know the intellectual environment of the Płock cathedral chapter and its interests, especially as the entire historical book collection of the library of the Seminary in Płock was taken by the Germans to Königsberg in 1941, see W. Graczyk, J.M. Marszalska, Księgi rękopiśmienne i stare druki w zbiorach biblioteki Wyżzzego Seminarium Duchownego w Ptocku. Z dziejów kultury polskich bibliotek kościelnych $w$ dawnych wiekach, Krakow 2010, pp. $29-35$ (there is also literature on the aforementioned topic).

2 W. Graczyk, Pawet Giżcki, biskup plocki (1439 - 1463), Płock 1999, p. 96; T. Silnicki, Husytyzm, in: Historia Kościoła w Polsce, vol.1, till 1764, part 1 till 1506, in: Historia Kościoła w Polsce, eds B. Kumor, Z. Obertyński, Poznań - Warszawa 1974, pp. 329 -334.
} 
Council in I2I5 as an exclusive privilege for the clergy; depriving the clergy of secular power; secularization of clerical property; punishing mortal sins by secular authority.

The program of Church reform advocated by Jan Hus (ca. I370-I4I5), thus outlined and formulated, became the subject of inquiries by Catholic theologians in their struggle against his views. ${ }^{4}$ They were given a lot of attention in theological treaties, which were imported from abroad to large urban centres, especially where cathedral chapters functioned and in Krakow University. It is worth noting that Stanisław of Skarbimierz (ca. I360-I43I) was the most representative Hussite polemic of the I5th century university milieu of Krakow (until I430). He encountered the Hussite problem as the rector of the Krakow Academy during the visit Hieronymus of Prague to Krakow. ${ }^{6}$ Somewhat later (in the conciliarist period), Polish theological thought on this subject was represented by Jan Elgot (c.I398-I452) 7 and Benedykt Hesse (c.I389-I456) ${ }^{8}$ fighting in their writings and speeches against Hussitism from the conciliarist position. ${ }^{9}$ As indicated in the treatises preserved after master Benedict Hesse, they used the legal output of the Italian canonist Franciszek Zabarella (I360-I4I7), the French reformer and poet Jan Gerson (I363-I428), and the Krakow scholastic and theologian Matthew of Krakow (ca. I330-I4IO). ${ }^{10}$

In I420, the Archbishop of Gniezno, Mikołaj Trąba (c.I358-I422) ordered special vigilance for people who came from Bohemia. This included, among other things, checking the contents of the collections of books held by the clergy, the destruction of writings considered heretical, and control of schools and teachers. The archbishop was supported by the King Wladyslaw Jagiello, who, in an edict issued in Wielun on I4 April, I423, ordered bishops or inquisitors appointed by him to examine the orthodoxy of people coming from Bohemia, while those who prolonged their stay in the country were to be regarded as heretics punishable by confiscation of goods or deprivation of nobility. .I The Statutes of Nicholas Trąba ordered suspects of heresy to appear before the court along with the books, and in the trials' records it is clearly stated that the accused had a book, and some of them even many books. ${ }^{12}$ Therefore,

\footnotetext{
3 J. Walkusz, Husytyzm, Cztery artykuły praskie, in: Encyklopedia Katolicka, vol. 6, ed. J. Walkusz, Lublin 1993, col. $1345-1348$.

4 M. Rechowicz, Po założeniu Wydziału Teologicznego w Krakowie (wiek XV), in: Dzieje teologii katolickiej w Polsce, vol. 1, Sredniowiecze, ed. M. Rechowicz, Lublin 1974, pp. 133 - 134.

5 R. Skrzyniarz, Stanisław ze Skarbimierza (ok. 1360 -1431), in: Encyklopedia Katolicka, vol. 18, ed. E. Gigilewicz, Lublin 2013, col. 800 - 801.

6 K. Dola, Hieronim z Pragi (ok.1380 - 1416), in: Encyklopedia Katolicka, vol. 6, ed. J. Walkusz, Lublin 1993, col. 858 - 859 .
}

7 W. Wójcik, Elgot Jan (ok.1380 - 1416), in: Encyklopedia Katolicka, vol. 4, ed. L. Bieńkowski, Lublin 1989, col. $884-885$.

8 S. Wielgus, Benedykt Hesse (ok.1389 - 1456), in: Encyklopedia Katolicka, vol. 6, ed. J. Walkusz, Lublin 1993, col. $812-814$.

9 M. Rechowicz, Po założeniu Wydziału Teologicznego w Krakowie (wiek XV), in: Dzieje teologii katolickiej w Polsce, vol. 1, Średniowiecze, pp. 137, 141.

10 Ibidem.

11 W. Graczyk, Pawet Giżycki, biskup płocki (1439-1463), pp. 96 - 97; For visitations of the diocese ordered by Trąba's statutes, sets of questions that the inspectors were required to ask had been prepared. Two of them were preserved: Modus inquirendi super statu ecclesiae and Ordo visitationis. They contain specially arranged questions for the detection of Hussitism. It was, therefore, a further manifestation of the struggle by the Polish clergy against the spreading heresy. See T. Silnicki, Husytyzm, in: Historia Kościoła w Polsce, vol. 1, to 1764, part. 1 to 1506, in: Historia Kościoła w Polsce, p. 332.

12 P. Buchwald-Pelcowa, Cenzura w dawnej Polsce. Między prasa drukarska a stosem, Warszawa 1997, p. 13. 
a book was regarded not only as an object of crime but also as its evidence, confirming the guilt of the person tried on charges of heresy, and diocesan visitors were to browse books held by priests in parishes in search of heretical writings of Hus and Wycliffe (c.I329 -I384), who were considered heretics. ${ }^{13}$

In the $15^{\text {th }}$-century ecclesiastical milieu of Płock, there were discussions on the issues of conciliarism, reform of the Church and on Hussitism ${ }^{14}$, which at that time became a serious threat to religious unity in Poland. The bishop of Płock, Paweł Giżycki (I439 - I463) ${ }^{15}$ was aware of this and imposed on archdeacons an obligation to examine the orthodoxy of clergy coming from Prague, usually after their studies. If the examination was unfavourable for the person concerned and the same person was an ecclesiastical beneficiary, the bishop ordered the initiation of actions aimed at removing him from the presbytery he occupied. Moreover, he forbade studying in Prague and going to that city: item de Consilio capituli episcopus mandavit fieri processus et inhiberi, ne clerici vadant ad studium in predictum Bohemie. ${ }^{16}$

It is worth noting that in the second half of the I4th century and in the first half of the $5^{\text {th }}$ century the Płock clergy studied in several academic centres: in Bologna ( 5 persons), Paris (2 persons), Padua (I person), Florence (I person), Prague (II persons) and in unidentified academic centres (5 persons). ${ }^{17}$ In the capital city of Krakow, 15 priests were studying at that time. Thus, apart from Krakow, Prague was the most important university centre to which students were going to continue their education. The third place was taken by the University of Bologna. The necessary books for further education were brought to Poland from these centres, as evidenced by numerous entries concerning the purchases and binding of many books acquired outside the borders of the country. From this period, two manuscripts (later found in the resources the cathedral library in Płock), containing materials from the meetings of the Basel Council, are worth mentioning. Their content played a significant role in shaping the ecclesiastical and political awareness of the Płock cathedral clergy.

The fact that Hussite affairs were of concern is evidenced by the numerous glosses in the margins of the cards related to treatises (speeches) and sermons from that period of on-going dispute between the supporters of Hussitism and its opponents. Probably one of such codes was drawn up in Basel in I433 by order of the Płock custodian John, son of Gotard of Moszna and Miłobędzin ${ }^{18}$, a close associate the bishop of Płock, Paweł. The fact that the code was studied and used in Płock is evidenced, among others, by the inclusion of the text: Occisio domini Werneri episcopi plocensis, in which on c. 306 - 3I3 (Incipit) it was written: Ex tractatu pre scripti materia tam quam ex quodam fundamento, and also

\footnotetext{
13 Ibidem.

14 E. Potkowski, Książka rękopiśmienna w kulturze Polski średniowiecznej, Warszawa 1984, p.156.

15 W. Graczyk, Pawet Gizycki, biskup plocki (1439-1463), p. 103 (there is also literature on the aforementioned topic).

16 Ibidem.

17 A. Radzimiński, Prałaci i kanonicy kapituły katedralnej płockiej w XIV i I pot. XV w. Studium prozopograficzne, vol. 1, Prałaci, Toruń 1991, p. 43.

18 M. Rechowicz, Po założeniu Wydziatu Teologicznego w Krakowie (wiek XV), in: Dzieje teologii katolickiej w Polsce, vol. 1, Średniowiecze, pp. 137; 141. On January 14, 1442, the Bishop of Płock, Paweł Giżycki, granted to Jan, the custodian, the village Gąsewo, situated in the Wyszogrod region, together with tithes, while the Płock chapter on February 3, 1445 approved the granting of tithes in Miłobędzin by Paweł Bishop of Płock. These grants may indicate that Jan was Bishop Paweł Giżycki's very close and trusted man.
} 
a provenience note: Scriptus in civitate Basiliensi tempore Concilii MCCCCXXXIII etc. Pontificatus domini Eugenii pape Quarti etc.pro Jo[hanne] custode Plocensi. ${ }^{19}$

Custodian John, the above-mentioned son of Gotard of Moszna and Miłobędzin, represented the Bishop of Płock, Paweł Giżycki, the cathedral chapter of Płock, and the Dukes of Mazovia at the Council in Basel. During the Council's deliberations, he gave a speech at the general meeting on April II, I432. ${ }^{20}$

The second of the handwritten manuscripts with a similar set of texts was probably - as Edward Potkowski wrote - created in Płock. ${ }^{21}$ Both codices contained polemical treaties and anti-Hussite speeches directed against the Four Articles of Prague written by Hus' followers: John of Ragusa (Ioannis de Ragusio), with the treatises: De communione sub utraque specie and Septem regulae ad habendum verum sensum sacrarum scripturarum; Jerome of Prague (Hieronymi Pragensis), with the sermon treatise: Sermo; Gilles Charlier (Aegidus Carlerii), with the treatise: De punitione peccatorum publicorum; Henryk Kalteis, (Henrici Kalteisen), with the treatise: Oratio de libera predicatione verbi Dei; John of Palomar, (Ioannis de Palomar), with the treatise: De civili domino clericorum. Moreover, the following writings were included: Excerpta ex Summa Benedicti abbatis Massiliae contra errores haereticorum; Responsiones ad obiectiones et pictura Ioannis Hus, Cardinal Julian Cesarini's treatise: Oratio ad convertendos Bohemos, and John de Bachenstein's treatise: decretorum doctoris, Sermo in concilio Basiliensi. ${ }^{22}$

Between the acts constituting the content of the code, there is a frequently encountered response of the aforementioned John of Ragusa to the articles of John of Rokycany, regarding the reception of Holy Communion in two forms as well as a sermon, In octavo Pasche by Jerome the Camaldolese of Prague, (confessor of Wladyslaw Jagiello) and John of Palomar's, Responsiones cardinalis Oratio ad convertendos Bohemos. ${ }^{23}$

Therefore, the theological literature in the resources of the medieval cathedral library in Płock was practically oriented, and in the Płock milieu - as it has already been mentioned the theological polemics of that time were familiar to the public. This is evidenced by the mentioned codes containing polemic treatises and anti-Hussite speeches, especially those directed against the Four Articles of Prague, written by John of Raguza, Jerome of Prague, Gilles Charlier, Henryk Kalteisen, John of Palomar, and Julian Cesarini. In addition to the aforementioned texts, the two mentioned Płock codices also contained excerpts from Benedict of Marseille's anti-heretical summa, reform decrees, and other writings of the Basel Council.

\footnotetext{
19 J. Korzeniowski, Zapiski z rękopisów Cesarskiej Biblioteki Publicznej w Petersburgu i innych bibliotek petersburskich. Sprawozdanie z podróży naukowych odbytych w latach 1891 -1892 i 1907, Kraków 1910, pp. 69 - 70; E. Potkowski, Ksiażka rękopiśmienna w kulturze Polski średniowieczne., p.156; to find more see Footnote no. 182.

20 A. Radzimiński, Prałaci i kanonicy kapituly katedralnej płockiej w XIV i I pot. XV w., vol.1, Prałaci, p. 101.

21 E. Potkowski, Książka rękopiśmienna w kulturze Polski średniowiecznej, p. 156, see Footnote no. 183.

22 A. Vetulani pointed out in his work that the identification of the above texts comes from Fr. Władysław Mąkowski, who inventoried the medieval collection of Płock. The manuscript code described here is the one missing from the Płock cathedral, ref. MS 73, cf. A. Vetulani, Średniowieczne rękopisy płockiej biblioteki katedralnej, pp. 425 - 426, with the author's information that the identification of the above texts comes from fr. W. Mąkowski; E. Potkowski, Książka rękopiśmienna w kulturze Polski średniowiecznej, p. 156.

23 M. Hornowska, H. Zdzitowiecka-Jasieńska, Zbiory rękopiśmienne w Polsce średniowiecznej, Warszawa 1947, pp. $294-295$.
} 
Due to numerous records and notes left on many pages, the canon law textbook by Cardinal Goffred of Trani, Summa super rubricis Decretalium24, was also of interest. The code, originating from southern Italy, has often changed ownership, was often borrowed and pledged as indicated by notes drawn up in different handwriting. Purchased, as noted: per Michaelem familiarem magistri Pauli de Zathor decretorum doctoris in duobus florenisa ureis25, it in time became the property of canon John, sitting in the collegiate chapter of St. Michael in Płock, as evidenced by the note kept on the front protective page of the code: Summa Goffredi fratris Johannis sacre theologiae magistri pro ecclesia Sancti Michaelis in Plock. ${ }^{26}$

Jakub Paszkowic of Piotrków (of bourgeois origin) was another holder of the abovementioned code; and it was probably he who left on the back of the book a short polemical text by Hus in defence of the burnt works of John Wycliffe (de libris hereticorum legendis), proving with the help of quotations from recognized ecclesiastical authorities the usefulness of reading heretical writings. ${ }^{27} \mathrm{He}$ is also credited with a note of a clearly radical-social sort (pro Hussite?), probably written in the Płock milieu: [...] Papa est servus beati Petri unde dicit se servus servorum dei... Servorum servi iuxta tibi sunt domini,[...] and further: $S i$ nobis pater est Adam, si mater est Eva, cur non ergo sumus nobilitate pare ${ }^{28}$ (If our father is Adam and mother is Eve, why then are we not of equal nobility by birth?). It cannot be ruled out that this short note had a hidden social overtone referring equality of the estates. A few remarks are due here to the canon of Płock, Jakub, son of Paszko of Piotrków (d. I447). ${ }^{29}$ His significant book collection of practical theology, the preaching aids (some with glosses and Polish texts on the margins) as well as treaties related directly to conciliarism, Hussite issues, and anti-Jewish polemics differed from the book collections of other Płock canons, which were dominated by legal subjects. It should be noted that Jakub Paszkowic collected books starting from his studies in Prague in the second half of the I4th century and then, in subsequent years of his life, as he held various ecclesiastical posts and beneficiaries, e.g. in Piotrków or in Radzanów near Płock. ${ }^{30}$

These books aided him in his pastoral work and were particularly useful during his service as a cathedral preacher in Płock. Hence, his book collection lacked legal works, while texts that were particularly important during the spread of Hussitism in the society of northern Mazovia dominated. ${ }^{\mathrm{I}}$

\footnotetext{
24 The manuscript code described here is the one missing from the cathedral of Płock, MS 16, cf. Średniowieczne rękopisy plockiej biblioteki katedralnej, pp. 388 - 391.

25 Ibidem, p. 391. Vetulani wrote them down from the autopsy. Paweł of Zator (+1463), a doctor of decrees, canon of Krakow and professor at the University of Krakow, mentioned in his note, left behind a collection of sermons De tempore de sanctis. He was also a preacher in the Krakow cathedral from 1423 to 1463. See J. Wolny, Kaznodziejstwo, in: Dzieje teologii katolickiej w Polsce, vol. 1, Średniowiecze, pp. 297 - 298.

26 The manuscript code described here is the one missing from the Płock cathedral, MS 16, cf. A. Vetulani, Średniowieczne rękopisy płockiej biblioteki katedralnej..., p. 391.

27 A. Radzimiński, Prałaci i kanonicy kapituly katedralnej płockiej w XIV i I pot. XV, vol. 1, Prałaci, pp. 61 - 62;

E. Potkowski, Książka rękopiśmienna w kulturze Polski średniowiecznej, p. 71, see Footnote no. 140.

28 Ibidem.

29 A. Radzimiński, Prałaci i kanonicy kapituły katedralnej płockiej w XIV i I pot. XV w., vol.1, Kanonicy, p. 18.

30 Ibidem.

31 Ibidem, p. 180; A. Vetulani, Średniowieczne rękopisy płockiej biblioteki katedralnej, p. 391.
} 
All texts touching on the Hussite issues were far from indifferent to the shaping of views and opinions of the people (mainly clerics) in the Płock cathedral milieu, and the milieu of the University of Krakow. They primarily intended to combat heretical movements, all anti-hierarchy and anti-clerical tendencies. Moreover, they indirectly informed about heretical doctrines, pointed out the contradictions between Church doctrine and the attitude of representatives of the Church hierarchy and the papal curia..$^{32}$ Probably modelled on these codes, another code with similar content to the above mentioned was created in Płock. It was a code proper to the aforementioned cathedral preacher and canon of Płock, Jakub of Piotrków ${ }^{33}$, who held the office of preacher in I429-I446, and whose library, rich in various books and preaching works, was regarded as exemplary in the milieu of the Płock cathedral. ${ }^{34}$

It is also worth noting that in the first half of the I5th century two professional copyists (married people), known by name as clericus coniugatus, found employment in the Płock cathedral scriptorium - Marcin of Gozdowo and the scriptor Piotr of Płock, whose son (by profession a furrier in Płock) was suspected of sympathy to Hussitism. ${ }^{35}$ On the work of Henryk Hostiensis, Summa aurea super quinto libro Decretalium, copyist Marcin of Gozdowo noted: per manus cuiusdam Martini clerici coniugati de Gosdowo in vigilia sanctorum Symonis et Jude apostolorum gloriosorum Anno domini MCCCCXLIIII. Explicit summa Hostiensi.$^{36}$

The code, dated around I444, was carefully written in bastarda font in two columns, with a small margin. As Adam Vetulani noted, on the front plank of its binding, as a (much later) sub-layer, a card was used with the text of the trial act of I486, the exhibitor of which was Arnoldus scolarius Cracoviensis. ${ }^{37}$ The backboard was covered with a text of the auditor of the Roman Rota, which was named: Johannis de Cehomariis de Bononia decretorum doctoris (under Pope Martin V) in a dispute Johannis Gothoconis clerici Gnesnensis diocesis against Stiborium Laurentii de Bedlsko rectorem ecclesie parochialis in Bodzanowo Plocensis diocesis..$^{8}$

It is worth noting here that in the chapter of Płock sat two relatives of the Przerów family; they were: Scibor the son of Wawrzyniec from Belsk, the archdeacon of Płock and his nephew - also Scibor, son of Wawrzyniec, who received the same prelature beneficiary of Bodzanów after the death of his uncle, who died in $1464 .{ }^{39}$ On the basis of the protocols of the meetings of the Płock chapter from I437-I445, it is known that on February 4, I440, at the general meeting, the Płock chapter obliged Scibor son of Wawrzyniec (the Elder) and his nephew, also Scibor son of Wawrzyniec (the Younger) to return the borrowed books: Rosarium and the said Decrees, belonging to the chapter..$^{40}$ Twelve years later - on September 8, I452, the archdeacon,

32 Ibidem, p. 161.

33 M. Kowalczyk, F. Belcarzowa, F. Wysocka, Glosy polskie Jakuba z Piotrkowa i innych autorów w rękopisach biblioteki Jagiellońskiej, „Biuletyn Biblioteki Jagiellońskiej”, vol. 23, (1973), pp. 84 - 86, see A. Radzimiński, Prałaci i kanonicy kapituly katedralnej płockiej w XIV i I pol. XV w...,p. 62.

34 J. Wolny, Kaznodziejstwo, in: Dzieje teologii katolickiej w Polsce, vol. 1, Średniowiecze, p. 299.

35 E. Potkowski, Książa rękopiśmienna w kulturze Polski średniowiecznej, p. 154.

36 The manuscript code described here is the one missing from the Płock cathedral, MS 16, cf. A. Vetulani, Średniowieczne rękopisy płockiej biblioteki katedralnej..., "Roczniki Biblioteczne", 7/ 1963, no. 3-4, pp. 394 - 395.

37 Ibidem, p. 394.

38 Ibidem, p. 395.

39 A. Radzimiński, Prałaci i kanonicy kapituly katedralnej płockiej w XIV i I poł. XV w..., vol. 1, Prałaci, pp. 145 -149 .

40 Ibidem, pp. 146, 147. 
Scibor the Elder, was sent along with the the archdeacon of Dobrzyń - Jakub of Kłodawa to examine the clergy and population of Płock suspected of spreading heresy. ${ }^{4 \mathrm{I}}$ Not without significance was the possession of books containing forbidden texts from the Hussite circle among the lower clergy, which aroused justified concern.

It was not without import that the lower clergy had books containing forbidden texts from the Hussite circle, which caused justified concern. On the other hand, the fact that married copyists were employed for the needs of the chapter library proved a high demand for manuscripts and that a relatively large number of people (canons) used books, hence the need to use their writing skills. Of peculiar curiosity is the information that the son of the scriptor Peter of Płock was suspected of liking Hussitism. In the autumn of I445, the chapter discussed the case of a Płock burgher - a furrier by profession - son of Jan, the above-mentioned book prescriber. The basis for the charge against him, resulting from a denunciation, was a suspicion of a good knowledge of heretical truths.

This case was not settled before the ecclesiastical court, but was handed over to the vogt and mayor of the city of Płock (secular power), about which the preserved documents inform: [...] qumodo quidem pellifex Plocensis civis, filius Petri scriptoris librorum, sit de heresi suspectus et articulos heresim sapientes tenet, et in eo facto decreverunt mittendum pro advocato et proconsule ad faciendum inquisicionem de predicto pellifice[...]. ${ }^{42}$

While until then the interest in Hussitism in the diocese had not gone beyond the clergy, the case mentioned above confirms that this phenomenon began to spread among the secular community of Płock and its surroundings. ${ }^{43}$ In this context, it is necessary to mention a very important legal code from the first half of the I5th century, which in the past had been owned by a prominent Płock lawyer, Mikołaj of Mirzyniec. This fact was confirmed by his inscription: [...]I448 XXVII septembris per Nicolaum Sdzeslai de Mirzinecz arcium magistrum, doctorem decretorum, licenciatum in iure civili canonicum Plocensem in Ploczsko hora (later completed) sed et officialem ac vicarium et 1463 administratorem ecclesiae Plocensis (with time, it was added) et iterum I47I administratorem. ${ }^{44}$ The work included 440 numbered decisions of the Roman Rota and was mostly written by Nicolaus of Mirzyniec. On the pages of the code marked with the numbering: $290 \mathrm{r}$. $-292 \mathrm{v}$. it was written: Hussica, a) Secuntur articuli Johannis Hus extracti de libris de ecclesia et quibusdam aliis tractatus eius. Unicae sanctae ecclesia, b) Secuntur articuli ex processibus contra Io. Huss sufficienter deducti et probati per testes fidedignos. Item primo articulus IIII et [...] in quibus continentur [...] sed fixistarent in veritate etc. Further on, there are formulas of oaths of people suspected of Hussitism. ${ }^{45}$

The aforementioned codex, marked by Adam Vetulani with the number MS 40, was undoubtedly studied carefully in the ecclesiastical milieu of Płock, which is evidenced by the use of a lawsuit to the Płock consistory as a bookmark, with a visible trace of the seal stamped on it. This work corresponded with the paper code of Polish origin from the beginning

\footnotetext{
41 Ibidem, pp. 147; $87-88$.

42 W. Graczyk, Paweł Giżycki, biskup płocki (1439 - 1463), p. 101, from: Acta Capitulorum Cracoviensis et Plocensis, no. 357, p. 93.

43 Ibidem.

44 The manuscript code described here is the one missing from the Płock cathedral, MS 40, cf. A. Vetulani, Średniowieczne rękopisy płockiej biblioteki katedralnej, pp. 410-413.

45 Ibid., p. 412.
} 
of the I5th century and based on the acts of the Włocławek consistory from I4O2 and I408. ${ }^{46}$ Just as in the code marked as MS 40 by Vetulani, so in the code marked as MS 39, the basic framework of legal monuments was identical, including the fact that on the first pages of both codices the following note was placed: Guilelmi Horborch, Decisiones Rotae Romanae, and the same texts were further inserted in a slightly different order. ${ }^{47}$

On the cards $249-250$ of the code marked as MS-39, the procedural forms (sententiae, diffinitivae, inhibitionis, absolutionis) from the Włocławek consistory were placed, and on the cards marked with the numbering 252 v. - 254, a general word Hussica was written, while on the cards from 253 to 254, Articuli Huss Johannis extracti de libro De Ecclesia was recorded. It was a fragment of the texts of oaths purifying those suspected of favouring Hussite novelties..$^{8}$ Adam Vetulani, who describes the analysed manuscript codes of Płock, does not say whether there was any mention of how and through whom the code marked as MS 39 had entered the medieval library of the Płock chapter. It cannot be ruled out that the code could have been borrowed for the needs of a copyist, and a different arrangement of basically the same material contained in the code (MS 39) supports that either the writer of one of them relied on the other code (MS 40), or both used a common model. ${ }^{49}$

The fact that Hussitism as an intellectual current, with a religious and social orientation, reached Mazovia is clearly evidenced by the books mentioned above and by marginal and provenience entries preserved on them, made out by Adam Vetulani before I939. Admittedly, these are not treatises that deal with the doctrine of the Church in the Hussite vision, but rather take issue with this movement. Thus, a manuscript in the ecclesiastical (cathedral) milieu of Płock in the I5th century, through its subject matter, was also used to defend the existing Catholic doctrine, rather than to conduct polemics with it. At the same time, through the mentioned books, one can see the interest of Płock, a city far away from the academic centre of Krakow, and of its clergy associated with the cathedral chapter, in the new religious current.

\section{Rękopiśmienna książka polemiczna w środowisku katedry płockiej w dobie sporów husyckich Streszczenie}

W XV-wiecznym kościelnym środowisku płockim obecne były dyskusje dotyczące spraw koncyliaryzmu, reformy Kościoła i husytyzmu, który w tym czasie stał się poważnym zagrożeniem jedności religijnej w Polsce. To, że interesowano się w Płocku sprawami husyckimi świadczą pozostawione na marginesach kart liczne glosy związane z zamieszczonymi w kodeksach traktatami (mowami) i kazaniami. Przechowywane kodeksy zawierały traktaty polemiczne i mowy antyhusyckie skierowane przeciw czterem artykułom praskim, których autorami byli zwolennicy Husa: Jan z Raguzy (Ioannis de Ragusio), z traktatem: De communione sub utraque specie oraz Septem regulae ad habendum verum sensum sacrarum scripturarum, Hieronim z Pragi zwany Mniszek, (Hieronymi Pragensis) z traktatem

\footnotetext{
46 The manuscript code described here is the one missing from the Płock cathedral, MS 39, cf. A. Vetulani, Sredniowieczne rękopisy płockiej biblioteki katedralnej, pp. 409-410.

47 Ibidem, p. 409.

48 Ibidem, p. 410

49 Ibidem, p. 359.
} 
kazanodziejskim: Sermo, Gilles Charlier (Aegidus Carlerii), z traktatem: De punitione peccatorum publicorum, Henryk Kalteis, (Henrici Kalteisen), z traktatem: Oratio de libera predicatione verbi Dei, Jan de Palomar,(Ioannis de Palomar), z traktatem: De civili domino clericorum, nadto zamieszczono pisma: Excerpta ex Summa Benedicti abbatis Massiliae contra errores haereticorum; Responsiones ad obiectiones et pictura Ioannis Hus, traktat kardynała Juliana Cesarini, Oratio ad convertendos Bohemos oraz traktat Jana de Bachenstein decretorum doctoris, Sermo in concilio Basiliensi. O tym że husytyzm jako prąd myślowy z ukierunkowaniem religijno-społecznym dotarł na Mazowsze, dobitnie świadczą przechowywane księgi i zachowane na nich wpisy marginalne i proweniencyjne, rozczytane przez Adama Vetulaniego jeszcze przed 1939 rokiem. Wprawdzie nie są to traktaty, które zajmują się doktryną Kościoła w ujęciu husyckim, co raczej polemiczne w stosunku do tego ruchu. Zatem książka rękopiśmienna w kręgu kościelnym (katedralnym) płockim w XIV stuleciu, poprzez swoją tematykę służyła również w obronie obowiązującej doktryny katolickiej, niż z nią prowadzonej polemiki. Jednocześnie poprzez wspomniane księgi widoczny jest fakt zainteresowania nowym prądem religijnym w znacznie odległym od ośrodka akademickiego krakowskiego - Płocka i jego duchowieństwa związanego z kapitułą katedralną.

Słowa kluczowe: Płock, średniowiecze, kapituła katedralna, husytyzm, kodeksy rękopiśmienne, traktaty polemiczne

\section{A polemical handwritten manuscript in the milieu of Plock cathedral at the time of the Hussite disputes Summary}

In the $15^{\text {th }}$-century ecclesiastical milieu of Płock, there were discussions on the issues of conciliarism, reform of the Church and on Hussitism, which at that time became a serious threat to religious unity in Poland. The fact that Hussite affairs were of concern is evidenced by the numerous glosses in the margins of the cards related to treatises (speeches) and sermons from that period of on-going dispute between the supporters of Hussitism and its opponents. The codices contained polemical treaties and anti-Hussite speeches directed against the Four Articles of Prague written by Hus' followers: John of Ragusa (Ioannis de Ragusio), with the treatises: De communione sub utraque specie and Septem regulae ad habendum verum sensum sacrarum scripturarum; Jerome of Prague (Hieronymi Pragensis), with the sermon treatise: Sermo; Gilles Charlier (Aegidus Carlerii), with the treatise: De punitione peccatorum publicorum; Henryk Kalteis, (Henrici Kalteisen), with the treatise: Oratio de libera predicatione verbi Dei; John of Palomar, (Ioannis de Palomar), with the treatise: De civili domino clericorum. Moreover, the following writings were included: Excerpta ex Summa Benedicti abbatis Massiliae contra errores haereticorum; Responsiones ad obiectiones et pictura Ioannis Hus, Cardinal Julian Cesarini's treatise: Oratio ad convertendos Bohemos, and John de Bachenstein's treatise: decretorum doctoris, Sermo in concilio Basiliensi. The fact that Hussitism as an intellectual current, with a religious and social orientation, reached Mazovia is clearly evidenced by the books mentioned above and by marginal and provenience entries preserved on them, made out by Adam Vetulani before I939. Admittedly, these are not treatises that deal with the doctrine of the Church in the Hussite vision, but rather take issue with this movement. Thus, a manuscript in the ecclesiastical (cathedral) milieu of Płock 
in the I4th century, through its subject matter, was also used to defend the existing Catholic doctrine, rather than to conduct polemics with it. At the same time, through the mentioned books, one can see the interest of Płock, a city far away from the academic centre of Krakow, and of its clergy associated with the cathedral chapter, in the new religious current.

Key words: Płock, Middle Ages, cathedral chapter, Hussitism, handwritten codices, polemical treaties

\section{BIBLIOGRAPHY}

\section{Printed sources}

Goffred de Trano, Summa super rubricis Decretalium, [call number MS - I6], in: Adam Vetulani, Średniowieczne rękopisy płockiej biblioteki katedralnej, „Roczniki Biblioteczne”, 7/1963, no. 3-4, pp. 388 - 39I.

Henryk Hostiensis, Summa aurea super quinto libro Decretalium, [call number MS - I9], in: Adam Vetulani, Średniowieczne rękopisy płockiej biblioteki katedralnej, „Roczniki Biblioteczne", 7/1963, no. 3-4, pp. 394 - 395.

Guilelmus Horborch, Decisiones Rotae Romanae, [sygn. MS - 39], in: Adam Vetulani, Średniowieczne rękopisy płockiej biblioteki katedralnej, „Roczniki Biblioteczne”, 7/1963, no. 3-4, pp. 409-4IO.

Nicolai de Mirzyniec, Tabula ad Quastiones determinante per rotam [k. 246-248r.] there texts: Hussica, a) Secuntur articuli Johannis Hus extracti de libris de ecclesia et quibusdam aliis tractatus eius. Unicae sanctae ecclesia, b) Secuntur articuli ex processibus contra Io. Huss sufficienter deducti et probati per testes fidedignos. Item primo articulus IIII et [...] in quibus continentur [...] sed fixistarent in veritate etc., [call number MS - 40], in: Adam Vetulani, Średniowieczne rękopisy płockiej biblioteki katedralnej, „,Roczniki Biblioteczne", 7/I963, no. 3-4, pp. 4IO-4I3.

Ioannis de Ragusio, De communione sub utraque specie and Septem regulae ad habendum verum sensum sacrarum scripturarum; Hieronymi Pragensis, Sermo, Aegidus Carlerii, De punitione peccatorum publicorum; Henrici Kalteisen, Oratio de libera predicatione verbi Dei; Ioannis de Palomar, De civili domino clericorum, besides, the following writings were included: Excerpta ex Summa Benedicti abbatis Massiliae contra errores haereticorum; Responsiones ad obiectiones et pictura Ioannis Hus; Julian Cesarini, Oratio ad convertendos Bohemos; Ioannis de Bachenstein decretorum doctoris, Sermo in concilio Basiliensi, [call number MS - 73], in: Adam Vetulani, Średniowieczne rękopisy płockiej biblioteki katedralnej, "Roczniki Biblioteczne” 7/1963, no. 3-4, pp. 425 - 426.

\section{Secondary sources}

Buchwald-Pelcowa P., Cenzura w dawnej Polsce. Między prasą drukarska a stosem, Warsaw 1997.

Dola K., Hieronim z Pragi (c. I380-I4I6), in: Encyklopedia Katolicka, vol. 6, ed. J. Walkusz, Lublin I993, col. 858 - 859 .

Graczyk W., Pawet Giżycki, biskup płocki (I439 - I463), Płock I999. 
Graczyk W., Marszalska J. M., Księgi rękopiśmienne i stare druki w zbiorach biblioteki Wyższego Seminarium Duchownego w Płocku. Z dziejów kultury polskich bibliotek kościelnych $w$ dawnych wiekach, Krakow 2010.

Hornowska M., Zdzitowiecka-Jasieńska H., Zbiory rękopiśmienne w Polsce średniowiecznej, Warsaw 1947.

Korzeniowski J., Zapiski z rękopisów Cesarskiej Biblioteki Publicznej w Petersburgu i innych bibliotek petersburskich. Sprawozdanie z podróży naukowych odbytych w latach I89I-I892 i I907, Krakow I9I0, pp. $69-70$.

Kowalczyk M., Belcarzowa F., Wysocka F., Glosy polskie Jakuba z Piotrkowa i innych autorów w rękopisach biblioteki Jagiellońskiej, „Biuletyn Biblioteki Jagiellońskiej”, vol. 23, (1973), pp. $84-86$.

Potkowski E., Książka rękopiśmienna w kulturze Polski średniowiecznej, Warsaw I984.

Radzimiński A., Prałaci i kanonicy kapituły katedralnej płockiej w XIV i I poł. XV w. Studium prozopograficzne, vol. I, Prałaci, Toruń I99I.

Rechowicz M., Po założeniu Wydziału Teologicznego w Krakowie (wiek XV) in: Dzieje teologii katolickiej w Polsce, vol. I, Średniowiecze, ed. M. Rechowicz, Lublin I974, s. 95-I44.

Silnicki T., Husytyzm, in: Historia Kościoła w Polsce, vol. I, till I764, part I till I506, in: Historia Kościoła w Polsce, eds B. Kumor, Z. Obertyński, Poznań - Warszawa I974, pp. $329-334$.

Skrzyniarz R., Stanisław ze Skarbimierza (c. I360 - I43I), in: Encyklopedia Katolicka, vol. I8, ed. E. Gigilewicz, Lublin 20I3, col. 800 - 80I.

Walkusz J., Husytyzm, Cztery artykuły praskie, in: Encyklopedia Katolicka, vol. 6, ed. J. Walkusz, Lublin I993, col. I345- I348.

Wielgus S., Benedykt Hesse (ok.1389 - I456), in: Encyklopedia Katolicka, vol. 6, ed. J. Walkusz, Lublin I993, col. 8I2 - 8I4.

Wójcik W., Elgot Jan (ok.I380 - I4I6), in: Encyklopedia Katolicka, vol. 4, ed. L. Bieńkowski, Lublin I989, col. $884-885$. 